P-ISSN: 2615-1723

E-ISSN: 2615-1766

Oktober 2019
Jurnal Riset Pendidikan Dasar

02 (2), (2019) 143-154

Submitted: Juli, Accepted Agustus, Published: Oktober

\title{
Analisis Pengaruh Motivasi Siswa Kelas III SD Inpres Paccerakang Kota Makassar dalam pembelajaran Membaca bahasa indonesia
}

\author{
Ummu Khaltsum
}

${ }^{1}$ Prodi Pendidikan Guru Sekolah Dasar, Fakultas Keguruan dan Ilmu Pendidikan Universitas Muhammadiyah Makassar, Indonesia

Korespondensi. E-mail: Ummukhaltsum@unismuh.ac.id

\begin{abstract}
Abstrak
Penelitian ini bertujuan untuk menganalisis motivasi siswa dalam pembelajaran membaca bahasa Indonesia. Jenis penelitian ini adalah penelitian deskripsi kuantitatif dalam bentuk persentase. Berdasarkan hasil analisis data, maka dapat dipaparkan suatu kesimpulan bahwa motivasi siswa kelas III SD Inpres Paccerakang kota Makassardalam pembelajaran membaca pada dasarnya dibagi atas dua bagian yaitu: motivasi yang bersifat eksternal dan motivasi yang bersifat internal. Motivasi siswa yang bersifat internal dalam aktivitas pembelajaran membaca masih tergolong rendah. Siswa III SD Inpres Paccerakang kota Makassar pada umumnya belum memiliki kesadaran yang mendalam dalam pembelajaran membaca. Siswa belum memahami pentingnya membaca dalam kehidupan manusia. Siswa lebih berminat dalam aktivitas menggambar daripada membaca buku pelajaran.
\end{abstract}

Kata Kunci: Analisis; Motivasi; Pembelajaran Membaca.

\section{Analysis of Influence of Motivation of Class III Students of SD Inpres Paccerakang Makassar}

\section{City in learning to read Indonesian}

\begin{abstract}
This study aims to analyze students' motivation in learning to read Indonesian. This research is a quantitative description of research in the form of a percentage. Based on the results of data analysis, it can be presented a conclusion that the motivation of third grade students of SD Inpres Paccerakang Makassard City in learning to read is basically divided into two parts, namely: external motivation and internal motivation. Student motivation that is internal in reading learning activities is still relatively low. Students III SD Inpres Paccerakang Makassar city in general do not yet have a deep awareness in learning to read. Students do not understand the importance of reading in human life. Students are more interested in drawing activities than reading textbooks.
\end{abstract}

Keywords: Analysis; Motivation; Reading Learning.

Copyright C2019, JRPD, ISSN 2615 - 1723 (Print), ISSN 2615 - 1766 (Online) 


\section{PENDAHULUAN}

Berbahasa pada dasarnya upaya untuk dapat menyatakan pikiran, gagasan dan maksud yang dapat diwujudkan secara kongkrit ke dalam bentuk ucapan baik lisan maupun tulisan. Kedua hal tersebut merupakan bentuk yang signifikan dari berbagai aspek yang perlu ditata dan dirapikan secara sistematis.

Pengajaran bahasa mempunyai arti yang cukup penting karena bahasa berfungsi sebagai media komunikasi yang perlu dikembangkan secara bertahap. Setiap siswa harus memahami penggunaan bahasa yang baik dan benar sehingga karya tulis ini dapat ditata lebih rapih dan sistematis, karena harus menfokuskan dirinya untuk mengetahui sejauh mana motivasi membaca siswa kelas III SD Inpres Paccerakang kota Makassar dalam mengikuti proses belajar-mengajar bahasa Indonesia.

Motivasi merupakan dorongan agar siswa dapat berfikir cermat dan punya pegangan kuat dalam mengikuti proses belajarmengajar bahasa Indonesia. Demikian pula proses belajar-mengajar di tingkat SDInpres Paccerakang kota Makassar yang diterapkan oleh seorang guru kadang sering berbeda terutama dalam pemberian materi tanpa adanya motivasi maka perlu diperhatikan dengan baik demi tercapainya proses pembelajaran yang efektif dan efisien.

Semangat dan motivasi belajar pada siswa tak ada bedanya dengan semangat dan motivasi bekerja atau berusaha dari guru ataupun orangtua. Ada kalanya semangat meningkat dan ada kalanya pula menurun. Ketika semangat dan motivasi belajar meningkat, guru ataupun orangtua hendaknya mempertahankan kondisi tersebut, dan ketika semangatnya turun, sudah seharusnya jika guru ataupun orangtua berupaya untuk meningkatkannya. Sebelum dapat meningkatkan semangat dan motivasi belajar siswa, guru ataupun orangtua tentu harus mengerti dan mengenali ciri-ciri dari menurunnya semangat dan motivasi belajar pada siswa.

Pada umumnya siswa apabila menghadapi buku atau bahan lainnya langsung saja mulai membaca kata pertama pada kalimat pertama, paragraf pertama, dari halaman pertama. Nampak tekun ditelusurinya kata demi kata, kalimat demi kalimat tetapi keadaanya tidak seperti yang kita harapkan. Hal ini disebabkan oleh kebiasaan lama yang salah dan menjadi tradisi yang turun temurun sehingga kecenderungan untuk memahami arti bacaan semakin lemah, tidak konsentrasi dan tidak berusaha menyelesaikan bacaannya.

\section{METODE}

Desain penelitian yang digunakan dalam penelitian ini adalah desain deskriptif. Penulis hanya mendeskripsikan tingkat motivasi siswa kelas III SD Inpres Paccerakang kota Makassar dalam pembelajaran membaca bahasa Indonesia.Instrumen yang digunakan dalam penelitian ini adalah berupa angket. Angket ini diperuntukkan untuk siswa dan guru kelas/bidang studi Bahasa Indonesia serta pengamatan langsung dalam aktivitas membaca siswa. Angket tersebut berjumlah 20 nomor, terdiri dari 15 nomor untuk siswa dan 5 nomor untuk guru kelas yang mengajar bidang studi Bahasa Indonesia.

Teknik pengumpulan data dalam penulisan ini yaitu:

1. Peneliti terlebih dahulu menyusun instrumen penelitian yang sesuai dengan judul yang telah ditetapkan.

2. Mengkonsultasikan kepada pihak sekolah mengenai waku yang tepat untuk mengadakan penelitian.

3. Peneliti mengedarkan angket kepada siswa sampel dengan memberikan petunjuk tertentu, khususnya mengenai cara pengisian angket tersebut. 
4. Mengawasi pengisian angket yang dilakukan oleh siswa sampel.

5. Mengumpulkan angket yang telah disebarkan sesuai dengan waktu yang telah ditentukan.

6. Mengadakan wawancara langsung terhadap guru dan siswa sampel yang berhubungan dengan membaca.

7. Mengamati secara langsung aktivitas membaca siswa yang diajarkan oleh guru kelas di SD tersebut.

Data yang diperoleh di lapangan dianalisis dengan menggunakan teknik analisis kualitatif, yaitu dengan mempersentasekan berbagai pernyataan siswa dalam angket telah disebarkan.

\section{HASIL DAN PEMBAHASAN}

Data dalam penelitian ini dianalisi sesuai dengan prosedur yang telah ditentukan pada bab terdahulu. Adapun data yang analisis yaitu data yang berupa hasil angket siswa dan hasil wawancara dengan guru kelas yang mengajar di kelas III SD Inpres Paccerakang kota Makassar. Data tersebut menggambarkan keadaan motivasi siswa dalam pembelajaran membaca di sekolah.

Hasil penelitian ini memberikan gambaran bagaimana motivasi siswa SD Inpres Paccerakang kota Makassardalam mengikuti pelajaran membaca. Penelitian ini sangat tepat dan bermanfaat dalam memacu peningkatan prestasi siswa di sekolah, baik mata pelajaran bahasa Indonesia maupun mata pelajaran lainnya. Hal ini merupakan modal dasar bagi siswa untuk memahami berbagai mata pelajaran lainnya di sekolah. Pelajaran lainnya tidak mungkin dapat dipahami dengan baik tanpa mengetahui membaca. Jadi, membaca merupakan kunci utama untuk memahami mata pelajaran lainnya. Untuk lebih jelasnya dapat dilihat hasil deskripsi data angket secara keseluruhan melalui tabel.

Berdasarkan tabel 1 di atas, maka secara keselurhan dapat diperoleh suatu gambaran tentang motivasi siswa kelas III SD Inpres Paccerakang kota Makassardalam hal pembelajaran membaca. Melalui data, maka dapat deskripsikan satu persatu dalam bentuk tabel.

Tabel1. Distribusi Angket Siswa SecaraKeseluruhan.

\begin{tabular}{|c|r|r|r|r|c|}
\hline No. & \multicolumn{4}{|c|}{ Alternatif Jawaban } & Jumla \\
\cline { 2 - 5 } Angket & A & \multicolumn{1}{|c|}{ B } & C & D & h \\
\hline 1. & 15 & 10 & 5 & 20 & 50 \\
2. & 22 & 8 & 13 & 7 & 50 \\
3. & 8 & 12 & 17 & 13 & 50 \\
4. & 16 & 22 & 7 & 3 & 50 \\
5. & 24 & - & 18 & 8 & 50 \\
6. & 6 & - & 24 & 10 & 50 \\
7. & 28 & 2 & 10 & - & 50 \\
8. & 30 & 15 & 5 & - & 50 \\
9. & 7 & - & 26 & 17 & 50 \\
10. & 11 & 9 & 15 & 17 & 50 \\
11. & 14 & 8 & 10 & 4 & 50 \\
12. & 16 & 4 & 11 & 9 & 50 \\
13. & 2 & - & 40 & 8 & 50 \\
14. & 29 & 2 & 10 & 9 & 50 \\
15 & 33 & 8 & 8 & 1 & 50 \\
\hline
\end{tabular}

Untuk lebih jelasnya dapat dilihat pada pemaparan tabel berikut beserta pembahasannya.

Tabel 2. Pembelajaran yang DisenangiSiswa di Sekolah.

\begin{tabular}{|c|c|c|c|}
\hline $\begin{array}{c}\text { No. } \\
\text { Angket }\end{array}$ & $\begin{array}{c}\text { Informasi } \\
\text { Siswa }\end{array}$ & $\begin{array}{c}\text { Frekuen } \\
\text { si }\end{array}$ & $\begin{array}{c}\text { Persen- } \\
\text { tase }\end{array}$ \\
\hline 1. & a. Membaca & 15 & 30 \\
& b. Menghitung & 10 & 20 \\
& c. Menulis & 5 & 10 \\
& d. & 20 & 40 \\
& Menggambar & & \\
\hline & Jumlah & 50 & 100 \\
\hline
\end{tabular}

Melalui tabel 2 dapat dideskripsikan bahwa di antara 50 siswa sampel ada 15 siswa atau $30 \%$ yang menyatakan pembelajaran yang disenangi siswa di sekolah adalah membaca. Ada 10 siswa sampel atau $20 \%$ yang menyatakan bahwa pembelajaran yang disenangi oleh siswa adalah menghitung. Ada 5 siswa sampel atau $10 \%$ yang menyatakan bahwa mata pelajaran yang disenangi siswa adalah menulis. Ada 20 siswa sampel atau

Copyright $\odot 2019$, JRPD, ISSN 2615 - 1723 (Print), ISSN 2615 - 1766 (Online) 
$40 \%$ yang menyatakan bahwa mata pelajaran yang disenangi siswa di sekolah adalah menggambar.

Sehubungan deskripsi data di atas, dapat disimpulkan bahwa pada umumnya siswa kelas III SD Inpres Paccerakang kota Makassarmenyatakan bahwa mata pelajaran yang paling disenangi adalah menggambar. Oleh karena itu, siswa perlu diberi pemahaman lebih lanjut tentang pentingnya membaca dalam kehidupan manusia, khususnya pada kalangan siswa di sekolah. Siswa tidak mungkin berhasil dengan baik dalam pelajarannya tanpa kehadiran membaca dalam aktivitasnya. Jadi, membaca merupakan kunci utama untuk meraih prestasi pembelajaran di sekolah.

Tabel3. Kesenangan Siswa Mengikuti Pembelajaran Membaca di Sekolah.

\begin{tabular}{|c|c|c|c|}
\hline $\begin{array}{c}\text { No. } \\
\text { Angket }\end{array}$ & Informasi Siswa & $\begin{array}{c}\text { Frekue } \\
\text { nsi }\end{array}$ & $\begin{array}{c}\text { Persen- } \\
\text { tase }\end{array}$ \\
\hline 2. & a. Sangat & 8 & 16 \\
& senang & 22 & 44 \\
& b. Senang & 13 & 26 \\
& c. Biasa saja & 7 & 14 \\
& d. Tidak senang & & \\
\hline & Jumlah & 50 & 100 \\
\hline
\end{tabular}

Berdasarkan data pada tabel di atas dapat dipaparkan bahwa di antara 50 siswa sampel ada 8 siswa atau $16 \%$ yang menyatakan sangat senang mengikuti pembelajaran membaca. Ada 22 siswa sampel atau $44 \%$ yang menyatakan bahwa siswa senang mengikuti pembelajaran membaca. Ada 13 siswa sampel atau $26 \%$ yang menyatakan bahwa siswa menganggap biasa saja mengikuti pembelajaran membaca. Ada 7 siswa sampel atau $14 \%$ yang menyatakan tidak senang mengikuti pembelajaran membaca di sekolah.

Sesuai deskripsi data di atas, maka dapat disimpulkan bahwa pada umumnya siswa

Copyright (C2019, JRPD, ISSN 2615 - 1723 (Print), ISSN 2615 - 1766 (Online) kelas III SD Inpres Paccerakang kota Makassarsenang mengikuti pelajaran membaca. Aktivitas membaca bagi siswa tingkat sekolah dasar (SD) memang sangat perlu diaktifkan dan mendapat perhatian khusus di sekolah. Guru harus selalu memberikan berbagai dorongan, petunjuk, dan pembinaan agar siswa dapat mahir dan terampil membaca.

Tabel 4. KeadaanMembaca Siswa Sebelum Masuk SD

\begin{tabular}{|c|c|c|c|}
\hline $\begin{array}{c}\text { No. } \\
\text { Angket }\end{array}$ & Informasi Siswa & $\begin{array}{c}\text { Freku } \\
\text { ensi }\end{array}$ & $\begin{array}{c}\text { Persen- } \\
\text { tase }\end{array}$ \\
\hline 3. & a. Sudah pintar & 8 & 16 \\
& b. Tahap mengeja & 12 & 24 \\
& c. Tidak tahu & 17 & 34 \\
& d. Sama sekali tidak & 13 & 26 \\
& tahu & & \\
\hline & Jumlah & 50 & 100 \\
\hline
\end{tabular}

Berdasarkan data pada tabel di atas, dapat dipaparkan bahwa di antara 50 siswa sampel ada 8 siswa atau $16 \%$ yang menyatakan sudah pintar. Ada 12 siswa sampel atau 24\% yang menyatakan baru tahap mengeja. Ada 17 siswa sampel atau 34\% yang menyatakan bahwa siswa tidak tahu membaca sebelum memasuki bangku sekolah dasar. Ada 13 siswa sampel atau $26 \%$ yang menyatakan sama sekali tidak tahu membaca sebelum memasuki jenjang sekolah dasar.

Sesuai deskripsi data di atas, maka dapat disimpulkan bahwa pada umumnya siswa kelas III SD Inpres Paccerakang kota Makassarmenyatakan tidak tahu membaca sebelum memasuki bangku sekolah dasar. Berdasarkan hasil wawancara dari guru yang mengajar di kelas III, nanti siswa berproses untuk tahu membaca dalam artian tahap mengeja setelah naik ke kelas II. Oleh karena itu, guru tidak boleh merasa bosan untuk memberikan pembinaan, dorongan, dan agar siswa dapat mahir dan terampil membaca. 
Tabel 5. Orang Pertama yang MengajariSiswa Membaca

\begin{tabular}{|c|c|c|c|}
\hline $\begin{array}{c}\text { No. } \\
\text { Angket }\end{array}$ & $\begin{array}{c}\text { Informasi } \\
\text { Siswa }\end{array}$ & Frekuensi & Persentase \\
\hline 4. & a. Guru & 18 & 36 \\
& b. Orang tua & 22 & 44 \\
& c. Kakak & 7 & 14 \\
& d. Diri sendiri & 3 & 6 \\
\hline & Jumlah & 50 & 100 \\
\hline
\end{tabular}

Berdasarkan data pada tabel di atas, dapat dipaparkan bahwa di antara 50 siswa sampel ada 18 siswa atau $36 \%$ yang menyatakan gurulah yang pertama kali yang mengajari membaca. Ada 22 siswa sampel atau $44 \%$ yang menyatakan orang tua yang pertama yang mengajari membaca. Ada 7 siswa sampel atau $14 \%$ yang menyatakan bahwa kakak yang pertama mengajari siswa membaca. Ada 3 siswa sampel atau 6\% yang menyatakan diri sendiri belajar membaca.

Sesuai deskripsi data di atas, maka dapat disimpulkan bahwa pada umumnya siswa kelas III SD Inpres Paccerakang kota Makassarmenyatakan bahwa orang tua yang pertama kali mengajari siswa membaca. Berdasarkan hal ini maka dapat dipertegas bahwa orang tua siswa tetap selalu mencurahkan perhatiannya untuk memotivasi anaknya agar cepat pintar membaca. Jadi, dorongan orang tua di rumah sangat diharapkan untuk membantu guru di sekolah dalam memperlancar proses pembelajaran, khususnya pembelajaran membaca.

Tabel 6. Kesenangan Siswa Membaca di Sekolah

\begin{tabular}{|c|c|c|c|}
\hline $\begin{array}{c}\text { No. } \\
\text { Angket }\end{array}$ & $\begin{array}{c}\text { Informasi } \\
\text { Siswa }\end{array}$ & Frekuensi & Persentase \\
\hline 5. & $\begin{array}{c}\text { a. Senang } \\
\text { b. Senang } \\
\text { sekali } \\
\text { c. Tidak } \\
\text { senang } \\
\end{array}$ & 24 & 48 \\
d. Biasa saja & 8 & 0 \\
\hline & Jumlah & 50 & 18 \\
\hline
\end{tabular}

Berdasarkan data pada tabel di atas, dapat dipaparkan bahwa di antara 50 siswa sampel ada 24 siswa atau $48 \%$ yang menyatakan senang siswa membaca di sekolah. Tidak ada siswa sampel atau $0 \%$ yang menyatakan senang sekali membaca di sekolah. Ada 18 siswa sampel atau 36\% yang menyatakan tidak senang membaca di sekolah. Ada 8 siswa sampel atau $16 \%$ yang menyatakan biasa-biasa saja membaca di sekolah.

Sesuai deskripsi data di atas, maka dapat disimpulkan bahwa pada umumnya siswa kelas III SD Inpres Paccerakang kota Makassarmenyatakan senang membaca di sekolah. Berdasarkan hal ini maka dapat diperjelas bahwa siswa tetap selalu merasa betah untuk membaca di sekolah. Hal ini merupakan suatu motivasi tersendiri bagi siswa untuk beraktivitas membaca di sekolah karena didukung lingkungan sekolah yang memadai, yaitu suasana tenang, sejuk, dan udara segar. Jadi, penentu kebijakan di sekolah tetap diharapkan memberikan dorongan agar siswa lebih senang dan giat membaca di sekolah.

Tabel 7. Keadaan Fasilitas Membaca diSekolah

\begin{tabular}{|c|c|c|c|}
\hline $\begin{array}{c}\text { No. } \\
\text { Angket }\end{array}$ & Informasi Siswa & $\begin{array}{c}\text { Frekuens } \\
\mathrm{i}\end{array}$ & $\begin{array}{c}\text { Persen- } \\
\text { tase }\end{array}$ \\
\hline 6. & a. Lengkap & 16 & 32 \\
& b. Sangat & - & 0 \\
& lengkap & 24 & 48 \\
& c. Kurang & 10 & 20 \\
& lengkap & & \\
& d. Sangat tidak & & \\
& lengkap & & \\
\hline & Jumlah & 50 & 100 \\
\hline
\end{tabular}

Berdasarkan data pada tabel di atas, dapat dideskripsikan bahwa di antara 50 siswa sampel ada 16 siswa atau $32 \%$ yang menyatakan fasilitas membaca di sekolah lengkap. Tidak ada siswa sampel atau 0\% yang menyatakan fasilitas pembelajaran membaca sangat lengkap. Ada 24 siswa

Copyright C2019, JRPD, ISSN 2615 - 1723 (Print), ISSN 2615 - 1766 (Online) 
sampel atau $48 \%$ yang menyatakan fasilitas pembelajaran membaca di sekolah kurang lengkap. Ada 10 siswa sampel atau $20 \%$ yang menyatakan sangat tidak lengkap fasilitas pembelajaran membaca di sekolah.

Sehubungan deskripsi data di atas, maka dapat disimpulkan bahwa pada umumnya siswa kelas III SD Inpres Paccerakang kota Makassarmenyatakan fasilitas pembelajaran membacanya kurang lengkap. Oleh karena itu, guru, kepala sekolah, dan seluruh penentu kebijakan lainnya agar mencurahkan perhatiannya untuk melengkapi fasilitas pembelajaran membaca di sekolah tersebut. Fasilitas yang dimaksud yaitu penyediaan koleksi bahan bacaan yang memadai, kursi/meja baca yang memuaskan, dan fasilitas lainnya yang berhubungan dengan pelajaran membaca.

Tabel 8. Anjuran Guru agar Siswa BerlatihMembaca di Rumah

\begin{tabular}{|c|c|c|c|}
\hline $\begin{array}{c}\text { No. } \\
\text { Angket }\end{array}$ & $\begin{array}{c}\text { Informasi } \\
\text { Siswa }\end{array}$ & $\begin{array}{c}\text { Frekue } \\
\text { nsi }\end{array}$ & $\begin{array}{c}\text { Persenta } \\
\text { se }\end{array}$ \\
\hline 7. & a. Sering & 28 & 56 \\
& b. Sering & 12 & 24 \\
& sekali & 10 & 20 \\
& c. Jarang & - & 0 \\
& d. Tidak & & \\
& pernah & & \\
\hline & Jumlah & 50 & 100 \\
\hline
\end{tabular}

Berdasarkan data tabel di atas, dapat dikemukakan bahwa di antara 50 siswa sampel ada 28 siswa atau $56 \%$ yang menyatakan guru sering menganjurkan siswa berlatih membaca di rumah. Ada 12 siswa sampel atau $24 \%$ yang menyatakan menyatakan guru sering sekali menganjurkan siswa berlatih membaca di rumah. Ada 10 siswa sampel atau $20 \%$ yang menyatakan guru jarang menganjurkan siswa berlatih membaca di rumah. Tidak ada siswa sampel atau 0\% yang menyatakan tidak pernah menganjurkan siswa berlatih membaca di rumah.
Sesuai deskripsi data di atas, maka dapat disimpulkan bahwa pada umumnya siswa kelas III SD Inpres Paccerakang kota Makassarmenyatakan bahwa guru sering menganjurkan siswa berlatih membaca di rumah. Langkah guru tersebut adalah suatu hal yang teapt untuk membekali potensi membaca siswa. Jadi, guru harus selalu mengarahkan agar seluruh siswa kelas III harus mampu dan pintar membaca sebelum naik ke kelas IV. Hal ini sesuai dengan fakta bahwa ternyata masih ada siswa yang sudah duduk di kelas yang lebih tinggi tetapi belum lancar dan mahir membaca. Kesalahan ini bukan hanya terdapat pada diri siswa itu sendiri, tetapi terkait dengan semua komponen di sekolah khususnya guru yang mengajar di kelas pemula pada tingkat sekolah dasar (SD).

Tabel 9. Keterlibatan Orang Tua Siswa Memberi Dorongan Berlatih Membaca

\begin{tabular}{|c|c|c|c|}
\hline $\begin{array}{c}\text { No. } \\
\text { Angket }\end{array}$ & $\begin{array}{c}\text { Informasi } \\
\text { Siswa }\end{array}$ & Frekuensi & $\begin{array}{c}\text { Pers } \\
\text { en- } \\
\text { tase }\end{array}$ \\
\hline 8. & $\begin{array}{c}\text { a. Sering } \\
\text { b. Sering } \\
\text { sekali }\end{array}$ & 30 & 60 \\
& $\begin{array}{c}\text { c. Jarang } \\
\text { d. Tidak } \\
\text { pernah }\end{array}$ & 5 & 10 \\
\hline & Jumlah & 50 & 100 \\
\hline
\end{tabular}

Sehubungan data pada tabel di atas, dapat dikemukakan bahwa di antara 50 siswa sampel ada 30 siswa atau $60 \%$ yang menyatakan orang tua sering terlibat memberikan dorongan dan latihan membaca siswa di rumah. Ada 15 siswa sampel atau $30 \%$ yang menyatakan orang tua sering sekali memberikan untuk berlatih membaca di rumah. Ada 5 siswa sampel atau 10\% yang menyatakan orang tua jarang memberikan dorongan siswa untuk belajar dan berlatih

Copyright C2019, JRPD, ISSN 2615 - 1723 (Print), ISSN 2615 - 1766 (Online) 
membaca di rumah. Tidak ada siswa sampel atau $0 \%$ yang menyatakan orang tua tidak pernah memberikan dorongan untuk berlatih membaca di rumah.

Sesuai deskripsi data di atas, maka dapat disimpulkan bahwa pada umumnya siswa kelas III SD Inpres Paccerakang kota Makassarmenyatakan bahwa pada umumnya siswa menyatakan orangtua sering terlibat dalam memberikan latihan dan dorongan membaca di rumah. Langkah orang tua siswa ini adalah suatu hal yang sangat tepat yang memiliki kepeduliaan yang tinggi terhadap peningkatan hasil pembelajaran membaca anaknya di sekolah. Hal ini merupakan suatu dorongan atau motivasi yang bersifat eksternal terhadap diri siswa dlam pembelajaran pembelajaran membaca anak di sekolah.

Tabel 10. Kondisi Kesadaran Siswa untuk Membaca

\begin{tabular}{|c|c|c|c|}
\hline $\begin{array}{c}\text { No. } \\
\text { Angket }\end{array}$ & Informasi Siswa & Frekuensi & $\begin{array}{c}\text { Persen- } \\
\text { tase }\end{array}$ \\
\hline 9. & a. Memiliki & 7 & 14 \\
& $\begin{array}{c}\text { b. Sangat } \\
\text { Memiliki } \\
\begin{array}{c}\text { c. Tidak ada } \\
\text { kesadaran } \\
\text { d. Acuh tak acuh }\end{array}\end{array}$ & - & 0 \\
\hline & Jumlah & 50 & 17 \\
\hline
\end{tabular}

Berdasarkan data pada tabel di atas, dapat dideskripsikan bahwa di antara 50 siswa sampel ada 7 siswa atau $14 \%$ yang menyatakan bahwa siswa memiliki kesadaran sendiri untuk membaca. Tidak ada siswa sampel atau $0 \%$ yang menyatakan sangat memiliki kesadaran diri sendiri untuk membaca. Ada 26 siswa sampel atau 52\% yang menyatakan tidak ada kesadaran diri siswa untuk membaca secara efektif. Ada 17 siswa sampel atau 34\% yang menyatakan acuh tak acuh atau sama sekali tidak memiliki kesadaran diri sendiri untuk belajar dan berlatih membaca dengan baik. Pada umumnya siswa belum memahami pentingnya membaca dalam aktivitas hidup manusia. Aktivitas membaca dianggapnya sebagai suatu hal yang biasa-biasa saja.

Sehubungan deskripsi data di atas, maka dapat disimpulkan bahwa pada umumnya siswa kelas III SD Inpres Paccerakang kota Makassarmenyatakan bahwa tidak memiliki kesadaran diri sendiri untuk belajar dan berlatih membaca. Hal ini membuktikan bahwa siswa tidak memiliki motivasi atau dorongan yang bersifat internal. Padahal motivasi yang bersifat internal ini adalah suatu hal yang sangat penting artinya dalam memacu peningkatan kualitas pembelajaran membaca di sekolah. Siswa yang memiliki motivasi yang bersifat internal mudah diarahkan dan dibina dalam pembelajaran membaca di sekolah.

Tabel 11. Hal yang Membuat Siswa Termotivasi Membaca

\begin{tabular}{|c|c|c|c|}
\hline $\begin{array}{c}\text { No. } \\
\text { Angket }\end{array}$ & $\begin{array}{l}\text { Informasi } \\
\text { Siswa }\end{array}$ & $\begin{array}{c}\text { Frekuens } \\
i\end{array}$ & $\begin{array}{c}\text { Persentas } \\
\mathrm{e}\end{array}$ \\
\hline \multirow[t]{5}{*}{10.} & Ingin & 11 & 22 \\
\hline & tahu & 9 & 18 \\
\hline & buku & 10 & 20 \\
\hline & $\begin{array}{l}\text { b. Ikut- } \\
\text { ikutan } \\
\text { c.Bukunya } \\
\text { baru } \\
\text { d. Perintah } \\
\text { guru }\end{array}$ & 20 & 40 \\
\hline & Jumlah & 50 & 100 \\
\hline
\end{tabular}

Berdasarkan data pada tabel di atas, dapat dideskripsikan bahwa di antara 50 siswa sampel, ada 11 siswa atau $22 \%$ yang menyatakan bahwa yang membuat siswa termotivasi membaca adalah rasa ingin tahu isi buku. Ada 9 siswa sampel atau 18\% menyatakan bahwa yang membuat siswa termotivasi membaca adalah karena ikutikutan dalam membaca. Ada 10 siswa sampel atau 20\% yang menyatakan bahwa termotivasi

Copyright (C2019, JRPD, ISSN 2615 - 1723 (Print), ISSN 2615 - 1766 (Online) 
siswa membaca karena memiliki buku baru. Ada 20 siswa sampel atau $40 \%$ yang menyatakan bahwa yang membuat siswa termotivasi membaca karena adanya perintah guru.

Sehubungan deskripsi data di atas, maka dapat disimpulkan bahwa pada umumnya siswa kelas III SD Inpres Paccerakang kota Makassarmenyatakan bahwa yang membuat siswa termotivasi membaca karena adanya perintah dari guru kelas. Hal ini membuktikan bahwa siswa masih rendah motivasi membacanya khususnya motivasi yang bersifat internal. Motivasi ini perlu dibangun dan dibekali oleh seluruh peserta didik, agar dapat maju berkembang dalam memcapai prestasi pembelajarannya.

Tabel 12. Kondisi Sarana Pembelajaran Membaca di Sekolah

\begin{tabular}{|c|c|c|c|}
\hline $\begin{array}{c}\text { No. } \\
\text { Angket }\end{array}$ & Informasi Siswa & $\begin{array}{c}\text { Freku } \\
\text { ensi }\end{array}$ & $\begin{array}{c}\text { Persen- } \\
\text { tase }\end{array}$ \\
\hline 11. & $\begin{array}{c}\text { a. } \\
\text { Menyenangkan } \\
\text { b. Sangat } \\
\text { menyenangkan } \\
\text { c. Tidak } \\
\text { menyenangkan }\end{array}$ & 12 & 40 \\
& 14 & 28 \\
& $\begin{array}{c}\text { d. Sangat Tidak } \\
\text { menyenangkan }\end{array}$ & & 8 \\
\hline & Jumlah & 50 & 100 \\
\hline
\end{tabular}

Berdasarkan data pada tabel di atas, dapat dideskripsikan bahwa di antara 50 siswa sampel, ada 20 siswa atau $40 \%$ yang menyatakan bahwa kondisi pembelajaran di sekolah dianggap menyenangkan. Ada 12 siswa sampel atau 16\% menyatakan bahwa suasana pembelajaran membaca di kelas sangat menyenangkan. Ada 14 siswa sampel atau 28\% yang menyatakan bahwa suasana pembelajaran di sekolah tidak menyenangkan. Ada 4 siswa sampel atau $8 \%$ yang menyatakan bahwa suasana pembelajaran membaca di sekolah sangat tidak menyenangkan.
Sesuai deskripsi data di atas, maka dapat disimpulkan bahwa pada umumnya siswa kelas III SD Inpres Paccerakang kota Makassarmenyatakan bahwa suasana pembelajaran membaca di sekolah dianggap cukup menyenangkan. Kondisi pembelajaran seperti ini adalah suatu hal yang sangat diharapkan yang dapat menciptakan aktivitas pembelajaran secara optimal. Akhirnya, tercipta peningkatan prestasi pembelajaran khususnya pembelajaran membaca di sekolah.

Tabel 13. Cara Penyajian Guru dalam Pembelajaran Membaca

\begin{tabular}{|c|c|c|c|}
\hline $\begin{array}{c}\text { No. } \\
\text { Angke } \\
\mathrm{t}\end{array}$ & Informasi Siswa & $\begin{array}{c}\text { Frekuens } \\
\mathrm{i}\end{array}$ & $\begin{array}{c}\text { Perse } \\
\text { ntase }\end{array}$ \\
\hline 12. & a. Menarik & 16 & 32 \\
& b. Sangat & 14 & 28 \\
& menarik & 11 & 22 \\
& $\begin{array}{c}\text { c. Tidak menarik } \\
\text { d. Biasa saja }\end{array}$ & 9 & 18 \\
\hline & Jumlah & 50 & 100 \\
\hline
\end{tabular}

Berdasarkan data pada tabel di atas, dapat dideskripsikan bahwa di antara 50 siswa sampel, ada 20 siswa atau $40 \%$ yang menyatakan penyajian guru dalam pembelajaran membaca tergolong menarik. Ada 14 siswa sampel atau $28 \%$ menyatakan bahwa cara penyajian guru dalam pembelajaran membaca di kelas sangat menarik. Ada 11 siswa sampel atau $22 \%$ yang menyatakan bahwa cara penyajian guru dalam pembelajaran membaca di kelas sangat menarik. Ada 9 siswa sampel atau $18 \%$ yang menyatakan bahwa cara penyajian guru dalam pembelajaran membaca biasa-biasa saja.

Sesuai deskripsi data di atas, maka dapat disimpulkan bahwa pada umumnya siswa kelas III SD Inpres Paccerakang kota Makassarmenyatakan penyajian guru dalam pembelajaran membaca tergolong menarik. Kondisi penyajian pembelajaran seperti ini adalah suatu hal yang sangat diharapkan tapi masih perlu dicarikan cara-cara penyajian yang 
lebih efektif agar setiap siswa tertarik dan aktif dalam mengikuti proses pembelajaran tersebut.

Tabel 14. Hadiah yang Diberikan oleh Guru dalam Aktivitas Membaca

\begin{tabular}{|c|c|c|c|}
\hline $\begin{array}{c}\text { No. } \\
\text { Angket }\end{array}$ & $\begin{array}{c}\text { Informasi } \\
\text { Siswa }\end{array}$ & $\begin{array}{c}\text { Freku } \\
\text { ensi }\end{array}$ & Persentase \\
\hline 13. & a. Sering & 2 & 4 \\
& b. Sangat & - & 0 \\
& sering & 40 & 80 \\
& c. Tidak & 8 & 16 \\
& Pernah & & \\
& d. Sama sekali & & \\
& tidak pernah & & \\
\hline & Jumlah & 50 & 100 \\
\hline
\end{tabular}

Berdasarkan data pada tabel di atas, dapat dideskripsikan bahwa di antara 50 siswa sampel, ada 2 siswa atau $4 \%$ yang menyatakan bahwa sering mendapat hadiah dari guru dalam aktivitas pembelajaran membaca. Tidak ada siswa sampel atau $0 \%$ menyatakan bahwa sangat sering mendapat hadiah dari guru dalam aktivitas pembelajaran membaca. Ada 40 siswa sampel atau $80 \%$ yang menyatakan bahwa guru tidak pernah memberi hadiah dalam aktivitas pembelajaran membaca. Ada 8 siswa sampel atau 16\% yang menyatakan bahwa sama sekali tidak pernah mendapat hadiah dari guru dalam aktivitas membaca

Sesuai deskripsi data di atas, maka dapat disimpulkan bahwa pada umumnya siswa kelas III SD Inpres Paccerakang kota Makassarmenyatakan bahwa tidak pernah mendapatkan hadiah dari guru dalam pembelajaran membaca di sekolah. Pemberian hadiah kepada siswa adalah suatu hal yang sangat berarti walaupun dalam bentuk dan jumlah yang sangat kecil. Hal ini dapat menjadi motivasi terendiri dalam diri siswa untuk rajin dan giat dalam membaca, sehingga dapat menciptakan kualiatas pembelajaran membaca membaca di sekolah. Kebanyakan guru di sekolah menganggap sepeleh persoalan pemberian hadiah ini kepada siswa. Pada hal dilihat dari pengaruhnya itu sangat bermanfaat kepada diri siswa. Pemberian hadih yang Copyright O2019, JRPD, ISSN 2615 - 1723 (Print), ISSN 2615 - 1766 (Online) dimaksud bukan hanya dalam bentuk materi atau uang, akan tetapi dapat pula berbentuk kata-kata atau sikap guru yang menyengakan terhadap diri siswa. Pemberian motivasi seperti ini dapat berlangsung kapan saja dan di mana saja. Sungguh berbahagialah siswa yang mendapat hadiah atau penghargaan dari guru.

Tabel 15. Pemberian penilaian dalamAktivitas Membaca

\begin{tabular}{|c|c|c|c|}
\hline $\begin{array}{c}\text { No. } \\
\text { Angket }\end{array}$ & $\begin{array}{c}\text { Informasi } \\
\text { Siswa }\end{array}$ & $\begin{array}{c}\text { Frekuen } \\
\text { si }\end{array}$ & $\begin{array}{c}\text { Persentas } \\
\text { e }\end{array}$ \\
\hline 14. & a. Sering & 29 & 48 \\
& b. Sangat & 2 & 4 \\
& sering & 10 & 20 \\
& c. Tidak & & 18 \\
& pernah & 9 & \\
& d. sama sekali & & \\
& tidak pernah & & \\
\hline & Jumlah & 50 & 100 \\
\hline
\end{tabular}

Berdasarkan data pada tabel di atas, dapat dikemukakan bahwa di antara 50 siswa sampel, ada 29 siswa atau $48 \%$ yang menyatakan guru sering memberikan penilaian dalam aktivitas membaca. Ada 2 siswa sampel atau 4\% menyatakan bahwa guru sangat sering memberikan penilian dalam aktivitas pembelajaran membaca di sekolah. Ada 10 siswa sampel atau $20 \%$ yang menyatakan bahwa guru tidak pernah memberikan penilaian dalam pembelajaran membaca di sekolah. Ada 9 siswa sampel atau $19 \%$ yang menyatakan bahwa guru sama sekali idak pernah memberikan penilaian dalam aktivitas membaca.

Sesuai deskripsi data di atas, maka dapat disimpulkan bahwa pada umumnya siswa kelas III SD Inpres Paccerakang kota Makassarmenyatakan bahwa guru sering memberikan penilaian dalam pembelajaran membaca di sekolah. Pemberian penilaian setiap pembelajaran pada dasarnya dapat membangkitkan motivasi belajar siswa, apalagi kalau siswa itu sendiri mengetahui hasilnya dengan baik. Oleh karena itu, guru harus 
mengembalikan hasil pekerjaan siswa sebagai umpan balik dalam aktivitas belajar siswa.

Tabel 16. Pentingnya PembelajaranMembaca di Sekolah

\begin{tabular}{|c|c|c|c|}
\hline $\begin{array}{c}\text { No. } \\
\text { Angket }\end{array}$ & Informasi Siswa & $\begin{array}{c}\text { Freku } \\
\text { ensi }\end{array}$ & $\begin{array}{c}\text { Persent } \\
\text { ase }\end{array}$ \\
\hline 15. & a. Penting & 33 & 66 \\
& b. Sangat & 8 & 16 \\
& penting & 8 & 16 \\
& c. Tidak penting & 1 & 2 \\
& d. Tidak perlu \\
& ada & & \\
\hline & Jumlah & 50 & 100 \\
\hline
\end{tabular}

Berdasarkan data pada tabel di atas, dapat dideskripsikan bahwa di antara 50 siswa sampel, ada 33 siswa atau $66 \%$ yang menyatakan pembelajaran membaca di sekolah tergolong penting. Ada 8 siswa sampel atau $16 \%$ menyatakan bahwa pembelajaran membaca di sekolah tergolong sangat penting. Ada 8 siswa sampel atau 16\% bahwa pembelajaran membaca di sekolah adalah tidak penting. Ada 1 siswa sampel atau $2 \%$ yang menyatakan bahwa pembelajaran membaca di sekolah tidak perlu diadakan.

Sesuai deskripsi data di atas, maka dapat disimpulkan bahwa pada umumnya siswa kelas SD Inpres Paccerakang kota Makassarmenyatakan bahwa pembelajaran membaca di sekolah tergolong penting. Pernyataan siswa ini tidak sesuai dengan hasil realitas dan pengamatan. Hal ini terbukti bahwa siswa tidak giat dan aktif membaca kalau tidak diperintahkan oleh gurunya. Siswa lebih senang berkeliaran dan ribut daripada membaca buku di perpustakaan. Bahaka kenyataan masih ada siswa kelas III SD Inpres Paccerakang kota Makassarbelum pasih dan lancar membaca. Sebaiknya, siswa yang belum lancar membaca tidak perlu dinaikkan di kelas III, tapi perlu digodok di kelas II.
Berdasarkan hasil analisis data yang telah dikemukakan di atas, maka dapatlah dipaparkan bahwa motivasi siswa kelas III SD Inpres Paccerakang kota Makassardalam pembelajaran membaca pada dasarnya dapat dibagi atas dua bagian utama yaitu:

Motivasi pembelajaran membaca siswa kelas III SD Inpres Paccerakang kota Makassarsecara eksternal yaitu dorongan yang dialami oleh siswa dalam mengikuti pembelajaran membaca karena pengaruh dari luar. Pengaruh luar yang dimaksud meliputi pengaruh dari seorang guru, orang tua siswa, teman sekolah, dan pasilitas laiannya yang dapat merangsang semagat atau dorongan siswa untuk belajar membaca.Bentuk motivasi membaca secara eksternal yang dirasakan oleh siswa secara kongret yaitu adanya keterlibatan langsung oleh guru dalam memberikan motivasi dalam belajar membaca di sekolah secara formal. Guru yang mengajar di kelas III SD Inpres Paccerakang kota Makassarselalu memberikan motivasi secara intensif kepada siswa agar dapat mengikuti pembelajaran membaca secara maksimal. Tindakan guru tersebut yaitu selalu menganjurkan, memberi rangsangan membaca, dan pembinaan langsung secara tertib dan disiplin dalam pembelajaran membaca. Begitu pula guru selalu berusaha menciptakan suasana pembelajaran yang menyenangkan agar siswa dapat lehih tertarik dalam mengikuti pembelajaran membaca di sekolah. Jadi, guru selalu berusaha menerapkan metode pembelajaran secara bervariasi dan mutakhir. Melalui penerapan metode ini, siswa tertarik mengikuti pembelajaran membaca dengan baik.

Di sisi lain, guru tetap memberikan motivasi dalam bentuk penguatan yang berupa penghargaan dalam bentuk kata-kata dan sikap yang menyenangkan sehingga siswa tertarik dan termotivasi dalam membaca. Sebagai contoh siswa yang berhasil membaca dengan baik dan tepat 
guru mengajak siswa lainnya untuk memberikan tepuk tangan yang meriah. Begitu pula dengan penilaian secara langsung yang diberikan kepada siswa.

Dorongan atau motivasi lain ang bersifat eksternal yaitu dapat berupa perhatian khusus yang diberikan orang tua siswa di rumanhnya. Kebanyak orang tua siswa tetap melibatkan dirinya untuk membantu dan berlatih agar anaknya dapat berhasil . orang tua siswa berusaha menyediakan sarana dan fasilitas bacaan yang memadai yaitu menyediakan bukubuku bacaan dengan cara membeli atau meminjam.

Hal lain yang menjadi motivasi siswa dalam pembelajaran membaca yaitu penentu kebijakan berupaya semaksimal untuk menyediakan dan melenggapi sarana perpustakaan ssebagai wadah dalam aktivitas membaca di sekolah. Sarana perpustkaan yang dimasud yaitu penyediaan berbaga jenis koleksi buku, bacaaan baik yang berupa buku fiksi maupun nonfiksi. Begitupula berusaha menata ruang perpustakaan sehingga siswa dapat merasa betah untuk tinggal membaca di perpustakaan.

Motivasi secara internal yaitu memotivasi siswa yang dialami siswa dalam pembelajaran dalam pembelajar dari dalam diri siswa itu sendiri. Berdasarkan hasil pengamatan dan analisis data, telah ditemukan bahwa motivasi siswa secara internal yang berhubungan dengan pembelajaran membaca di sekolah, masih tergolong sangat rendah. Siswa kelas III SD Inpres Paccerakang kota Makassarbelum memiliki kesadaran yang mendalam untuk banyak berlatih dan mengikuti pembelajaran membaca di sekolah. Pada umumnya siswa belum memahami hakikat dan pentingnya aktivitas membaca dalam kehidupan manusia. Bahkan ditemukan siswa yang sama sekal itidak memiliki kepedualian terhadap aktvitas membaca. Oleh karena itu tidaklah mengherankan kalau ditemukan ada siswa yang belum mahir dan lancar membaca. Apalagi siswa tersebut memang dari awal sebelum masuk di bangku SD sama sekali belum mengenal jenis-jenis huruf karena tidak melewati pendidikan taman kanak-kanak.

Dilihat dari kesenangan siswa terhadap mata pelajaran yang dipelajari di sekolah khususnya siswa kelas III SD Inpres Paccerakang kota Makassarternyata terdapat kecenderungan lebih menyenangi pembelajaran menggambar dari pada membaca,. Hal ini membuktikan bahwa siswa belum memiliki kepedulian dan daya tarik tersendiri dalam pembelajaran membaca di sekolah. Oleh karena itu, guru selayaknya selalu memberikan petunjuk dan arahan dalam hal pembelajaran membaca di sekolah. Hal semua ini terjadi karena siswa belum menyadari sepenuhnya pentingnya membaca dalam kehidupan sehari-hari.

\section{SIMPULAN}

Berdasarkan hasil analisis data, maka dapat dipaparkan suatu kesimpulan bahwa motivasi siswa kelas III SD Inpres Paccerakang kota Makassardalam pembelajaran membaca pada dasarnya dibagi atas dua bagian yaitu: motivasi yang bersifat eksternal dan motivasi yang bersifat internal. Motivasi yang bersifat eksternal yaitu motivasi yang bersumber dari luar diri siswa itu sendiri. Bentuk motivasi ini yang dialami oleh siswa yaitu adanya keterlibatan langsung oleh guru kelas dalam memberikan arahan, petunjuk, bimbingan, penerapan metode yang bervariasi dan menyenangkan, perhatian khusus kepada siswa, pemberian penilaian secara langsung dalam pembelajaran membaca dan mengusahakan penyediaan sarana dan prasarana dalam pembelajaran membaca. Disamping itu, keterlibatan orang tua siswa berlangsung dengan baik. Orang tua siswa pada umumnyaikut terlibat dalam membina dan mendidik anaknya agar mahir dan terampil membaca.

$$
\text { Copyright C2019, JRPD, ISSN } 2615 \text { - } 1723 \text { (Print), ISSN } 2615 \text { - } 1766 \text { (Online) }
$$


Motivasi siswa yang bersifat internal dalam aktivitas pembelajaran membaca masih tergolong rendah. Siswa III SD Inpres Paccerakang kota Makassarpada umumnya belum memiliki kesadaran yang mendalam dalam pembelajaran membaca. Siswa belum memahami pentingnya membaca dalam kehidupan manusia. Siswa lebih berminat dalam aktivitas menggambar daripada membaca buku pelajaran.

\section{DAFTAR PUSTAKA}

Aini, I. (2006). Membaca dan Menulis Seasyik Bermain. Bandung: Read! Publishing House.

Asdam, M. (2006). Bahasa Indonesia Menuju Sukses. Makassar.

Cochran, W.G. (1991). Teknik Penarikan Sampel. Edisi ketiga, Jakarta: Universitas Indonesia (UI-Press).

Depdiknas. (1995), Kamus Besar Bahasa Indonesia. Edisi kedua, Jakarta: Balai Pustaka.

Dianawati, A. (2005). Membuat Anak Gemar Membaca.Yogyakarta: Antelo Press.

Komandoko, G. (2006). 20 Kiat Membangkitkan Motivasi Belajar Anak. Yogyakarta: Cakrawala.

Sardiman. A.S. (1985). Interaksi dan Motivasi Belajar-Mengajar. Jakarta: Rajawali.

Singgih, G.G. (1986). Psikologi Perkembangan. PI, BPK, Bandung: Gunung Mulia.

Soli, A. (1991). Interaksi Belajar Mengaiar. Ujung Pandang: FIP-IKIP.

Sudarsono. (2004). Speed Reading (Sistem Membaca Cepat dan Efektif) Cetakan Kesebelas. Jakarta: Gramedia Pustaka Utama.

Sudjana, (1994). Motode Statistik. Bandung: Tarsito.

Sumardi, S. (1994). Psikologi Pendidikan. Universitas Gajah Mada. Jakarta: Rajawali.

Supranto. (1996). Statistik (Teori dan Aplikasi), Edisi Kelima, Jakarta: Erlangga.
Winarno, Surachmat. (1992). Pengantar Interaksi Belajar-mengajar. Bandung: Tarsito. 